http://dx.doi.org/10.11646/zootaxa.3741.1.1

http://zoobank.org/urn:lsid:zoobank.org:pub:6B2E0F80-73A2-4F66-B1A6-2D9481EAAB74

\title{
Revisionary checklist of the Southern African Sesiini (Lepidoptera: Sesiidae) with description of new species
}

\section{DANIEL BARTSCH}

Staatliches Museum für Naturkunde Stuttgart, Rosenstein 1, 70191 Stuttgart. E-mail: daniel.bartsch@smns-bw.de

\section{Table of contents}

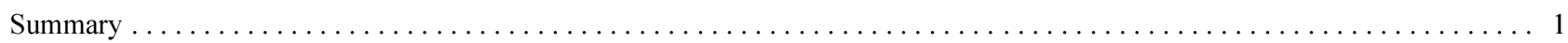

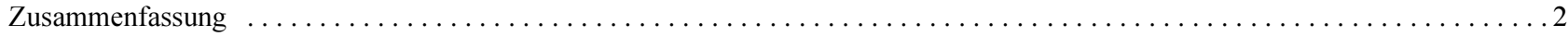

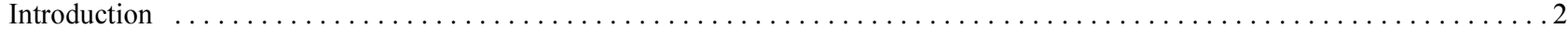

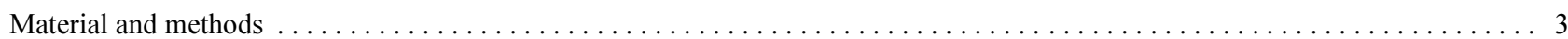

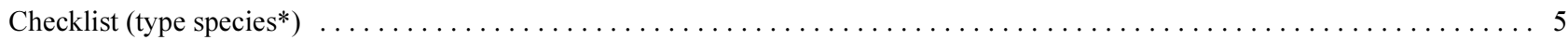

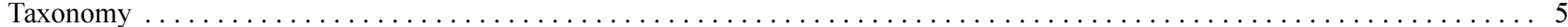

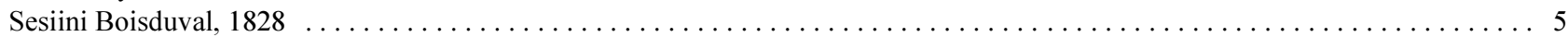

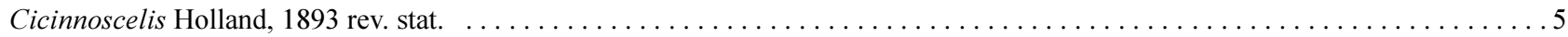

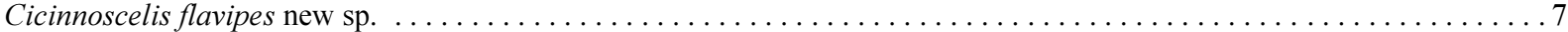

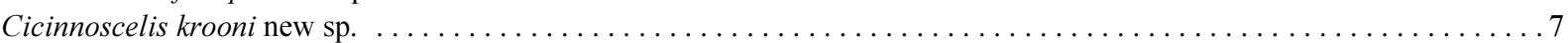

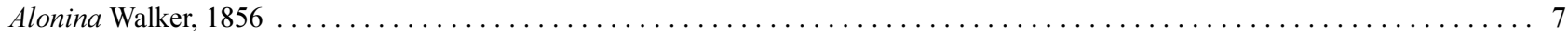

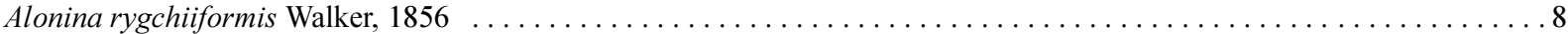

Alonina luteopunctata (Freina, 2011) new comb. (Monopetalotaxis) $\ldots \ldots \ldots \ldots \ldots \ldots \ldots \ldots \ldots \ldots \ldots \ldots \ldots \ldots \ldots$

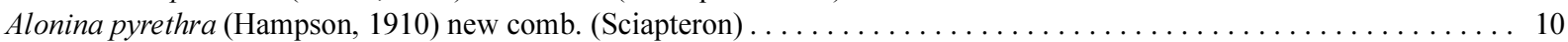

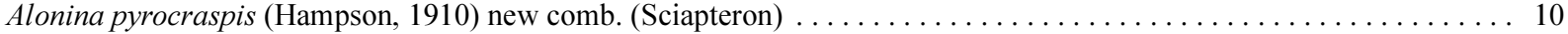

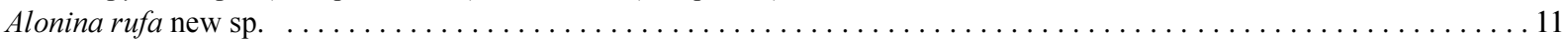

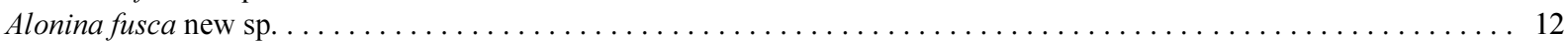

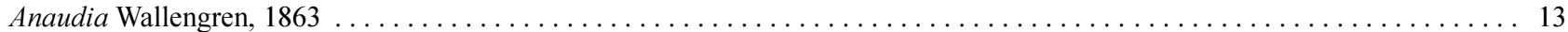

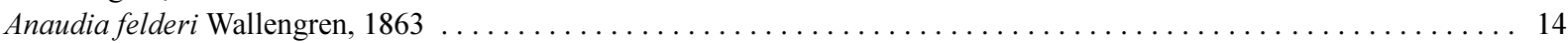

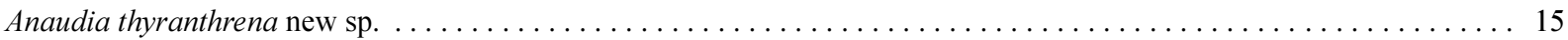

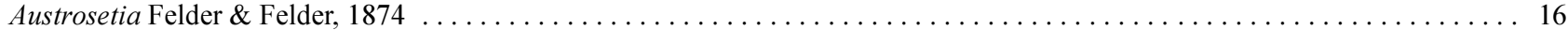

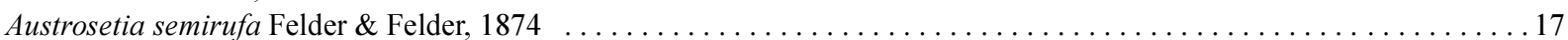

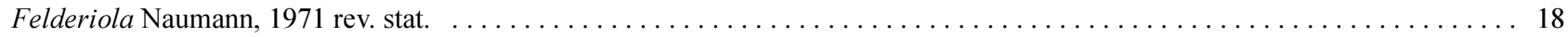

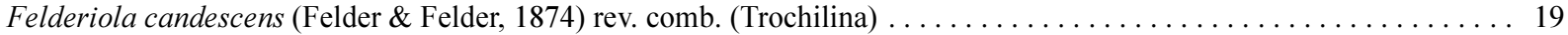

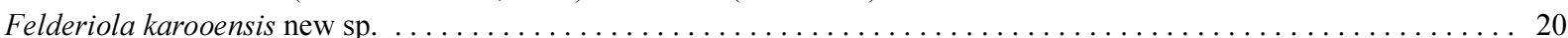

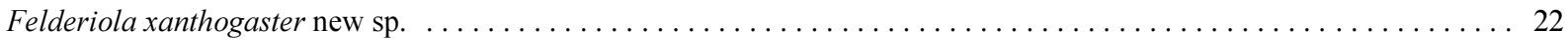

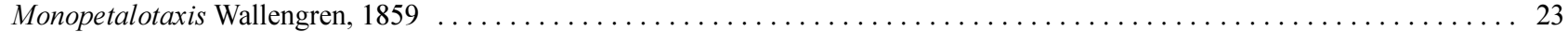

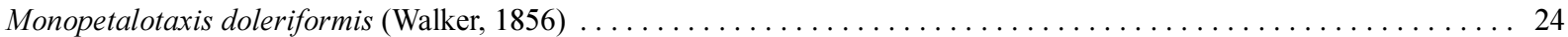

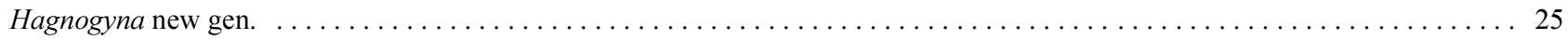

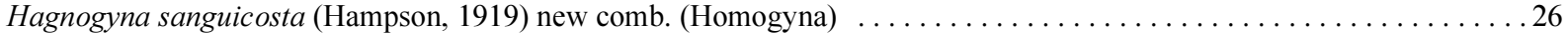

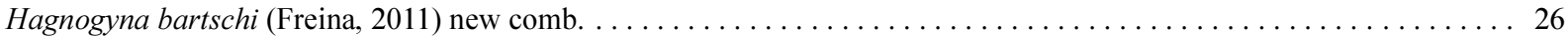

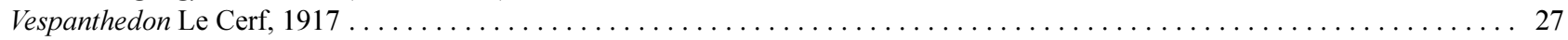

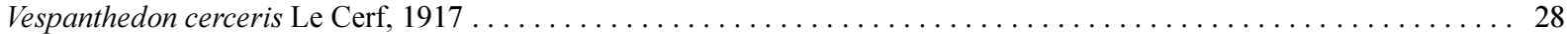

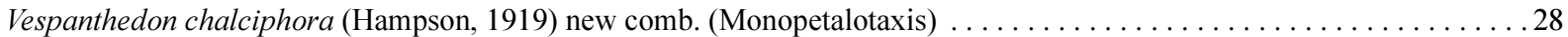

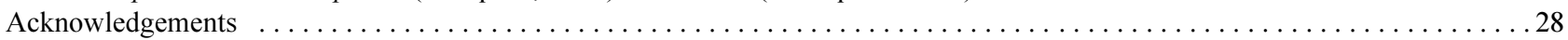

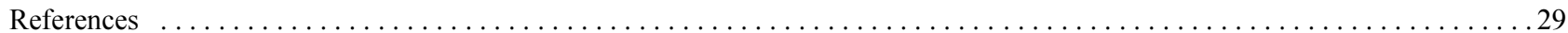

\section{Summary}

A revisionary checklist of the Sesiini of southern Africa is presented. All known genera of the region and their type species are redescribed. The following genera are placed in Sesiini for the first time: Alonina Walker, 1856; Anaudia Wallengren, 1863; Austrosetia Felder \& Felder, 1874; Megalosphecia Le Cerf, 1916 and Vespanthedon Le Cerf, 1917. The genera Cicinnoscelis Holland, 1893 rev. stat. (from synonymy with Alonina Walker, 1856) and Felderiola Naumann, 1971 rev. stat. (from synonymy with Monopetalotaxis Wallengren, 1859) are resurrected from synonymy and included in Sesiini. One new genus, Hagnogyna new gen., and seven new species, Cicinnoscelis flavipes new sp., C. krooni new sp., Alonina 
rufa new sp., A. fusca new sp., Anaudia thyranthrena new sp., Felderiola karooensis new sp. and F. xanthogaster new sp., are described. The following new combinations are introduced: Cicinnoscelis longipes Holland, 1893 rev. comb., Alonina pyrethra (Hampson, 1919) new comb., A. pyrocraspis (Hampson, 1910) new comb., A. luteopunctata (Freina, 2011) new comb., Felderiola candescens (Felder \& Felder, 1874) rev. comb., Hagnogyna sanguicosta (Hampson, 1919) new comb., $H$. bartschi (Freina, 2011) new comb. and Vespanthedon chalciphora (Hampson, 1919) new comb. Alonina difformis Hampson, 1919 new syn. is considered a subjective junior synonym of A. rygchiiformis Walker, 1856. A lectotype is designated for Austrosetia semirufa Felder \& Felder, 1874 and the previously unknown males of this species and of Anaudia felderi Wallengren, 1863 are described. Bionomical data for some of the species discussed are given for the first time.

Key words: descriptive taxonomy, systematics, synonymy

\section{Zusammenfassung}

Eine revidierte Checklist der Sesiini des südlichen Afrikas wird vorgestellt. Alle bisher aus der Region bekannten Gattungen einschließlich ihrer Typusarten werden wiederbeschrieben. Erstmals zu den Sesiini gestellt werden die Gattungen: Alonina Walker, 1856; Anaudia Wallengren, 1863; Austrosetia Felder \& Felder, 1874; Megalosphecia Le Cerf, 1916 und Vespanthedon Le Cerf, 1917. Aus der Synonymie genommen und ebenfalls den Sesiini zugeordnet werden: Cicinnoscelis Holland, 1893 stat. rev. (aus der Synonymie von Alonina Walker, 1856) und Felderiola Naumann, 1971 stat. rev. (aus der Synonymie von Monopetalotaxis Wallengren, 1859). Eine Gattung, Hagnogyna gen. nov., sowie sieben Arten $C i$ cinnoscelis flavipes sp. nov., C. krooni sp. nov., Alonina rufa sp. nov., A. fusca sp. nov., Anaudia thyranthrena sp. nov., Felderiola karooensis sp. nov. und F. xanthogaster sp. nov. werden beschrieben. Folgende nomenklatorischen Änderungen werden vorgenommen: Cicinnoscelis longipes Holland, 1893 comb. rev.; Alonina pyrethra (Hampson, 1919) comb. nov.; A. pyrocraspis (Hampson, 1910) comb. nov.; A. luteopunctata (Freina, 2011) comb. nov.; Felderiola candescens (Felder \& Felder, 1874) rev. comb.; Hagnogyna sanguicosta (Hampson, 1919) comb. nov.; H. bartschi (Freina, 2011) comb. nov.; Vespanthedon chalciphora (Hampson, 1919) comb. nov. Als subjektives jüngeres Synonym zu A. rygchiiformis Walker, 1856 wird Alonina difformis Hampson, 1919 syn. nov. angesehen. Ein Lectotypus von Austrosetia semirufa Felder \& Felder, 1874 wird festgelegt und die bisher unbekannten Männchen dieser Art sowie von Anaudia felderi Wallengren, 1863 werden beschrieben. Von einigen der hier besprochenen Arten werden erstmals bionomische Angaben mitgeteilt.

\section{Introduction}

Clearwing moths of the tribe Sesiini Boisduval, 1828 have a predominantly old world distribution. Only three species, all belonging to the Holarctic genus Sesia Fabricius, 1775, including the introduced European Sesia apiformis (Clerck, 1759), are known from the Americas (Eichlin \& Duckworth 1988, Eichlin \& Taft 1988, Pühringer \& Kallies 2004). The highest species diversity is known from the eastern and south-eastern parts of Asia with currently 86 species assigned to 10 genera (Špatenka et al. 1999, Pühringer \& Kallies 2004, Kallies \& Arita 2004, Heppner 2011, Kallies 2011). The current knowledge of the Afrotropical Sesiini fauna was gathered predominantly in recent years and is still fragmentary. Three nominal species of the genera Callisphecia Le Cerf, 1916 and Madasphecia Viette, 1982 were placed in Sesiini by Pühringer \& Kallies (2004). A review of the five Sesiini species of the Madagascan subregion belonging to the genera Hovaesia Le Cerf, 1957, Melittosesia Bartsch, 2009, Lenyrhova Le Cerf, 1957 and Madasphecia Viette, 1982 was published and the monotypic genus Afrokona Fischer, 2006 from Congo was transferred to Sesiini by Bartsch (2009). Freina (2011) placed five species of Monopetalotaxis Wallengren, 1859 in Sesiini and Pühringer \& Sáfián (2011) described Barbasphecia, a genus from Ghana comprising two species, in Sesiini. Meanwhile, the classification of the majority of African Sesiidae, in particular of the southern part (Namibia, South Africa, Botswana, Zimbabwe and Mozambique south of river Zambezi), was established and several genera as well as some misplaced species were regarded belonging to Sesiini (Vári, Kroon \& Krüger 2002). With currently fifteen recognized genera, all of which are endemic, the Afrotropical Sesiini fauna appears to be exceedingly diverse. So far, this diversity is not reflected by high numbers of described species, but, considering the insufficient level of exploration, this is not surprising. Just as in other regions of the world, the Afrotropical Sesiini includes some of the largest and most colourful Sesiidae species known, but also some inconspicuous and rather small species. 


\section{References}

Bartsch, D. (2008) A review of the Paranthrenini of the Afrotropical region (Lepidoptera, Sesiidae). Entomologische Zeitschrift, 118 (6), 265-280.

Bartsch, D. (2009) A new genus of clearwing moths with a review of the tribe Sesiini Boisduval, 1828 (Lepidoptera, Sesiidae) in Madagascar. Entomologische Zeitschrift, 119 (1), 9-16.

Boisduval, J.A. (1875) Sphingides, Sésiides, Castnides ["1874"]. Tribu des Sesiaires. Histoire Naturelle des Insectes. In: Boisduval, J.A. \& Guenée, A. (Ed.), Histoire Naturelle des Insectes. Species General des Lepidopteres Heteroceres, Librairie Encyclopedique de Roret, Paris, 1 (4), pp. i-iv + 1-568, pls. 1-11.

Clerck, C. (1759) Fig. 2, Sp. apiformis. Icones Insectorum Rariorum Cum Nominibus eorum trivialibus, locisque e C. Linnaei Arch. R. et Equ. Aur. Syst. Nat. allegatis. pl. 9, figs. 1-3.

Dalla Torre, K.W. \& Strand, E. (1925) Aegeriidae. Lepidopterorum Catalogus, 31. W. Junk, Berlin, 202 pp.

Eichlin, T.D. \& Duckworth, W.D. (1988) The Moths of America North of Mexico. Fascicle 5.1. Sesioidea, Sesiidae. The Wedge Entomological Research Foundation, $176 \mathrm{pp}$.

Eichlin, T.D. \& Taft, W.H. (1988) A new Sesia clearwing moth from Michigan (Sesiidae). Journal of the Lepidopterists' Society, 42 (3), 231-235.

Fabricius, J.C. (1775) VI. Glossata. 140. Sesia. Systema Entomologiae, sistens Insectorum classes, ordines, genera, species, adiectis synonymis, locis, descriptionibus, observationibus, (3), 547-549.

Fabricius J.C. (1807) Die neueste Gattungs-Eintheilung der Schmetterlinge aus den Linneischen Gattungen Papilio und Sphinx [44. Sesia. 45. Aegeria. 11. Sesia.]. In: Illiger (Ed.), Magazin für Insektenkunde, 6, 277-295.

Felder, C. \& Felder, R. (1874) Lepidoptera von Dr. Cajetan Felder, Rudolf Felder und Alois F. Rogenhofer. Atlas. [Sesiidae]. Reise der österreichischen Fregatte Novara um die Erde in den Jahren 1857, 1858, 1859 unter den Befehlen des Commodore B. von Wüllerstorf-Urbair. Zoologischer Theil. Zweiter Band. Zweite Abtheilung (fasc. 4), 2-9, pls. 75, 82.

Fischer, H. (2006) A new tribe, genus and species of clearwing moths from the Afrotropical Region (Lepidoptera: Sesiidae, Sesiinae). Atalanta, 37 (1/2), 219-224, pl. 7.

Fischer, H. (2006) Corrigendum zur Publikation "A new tribe, genus and species of clearwing moths from the Afrotropical Region" in Atalanta 37. Band, Heft 1/2 (Lepidoptera: Sesiidae, Sesiinae). Atalanta, 37 (3/4), 328.

Fletcher, D.S. (1982) Bombycoidea, Castnioidea, Cossoidea, Mimallonoidea. Sesioidea, Sphingoidea, Zygaenoidea. In: Nye, I.W.B. (Ed.), The Generic names of Moths of the World, Vol.4. British Museum (Natural History) Publication No. 848, London, $192 \mathrm{pp}$.

Fletcher, T.B. (1929) A list of the Generic Names used for Microlepidoptera. Memoirs of the Department of Agriculture in India, Entomological series 11, 1-244.

Freina, J.J.de (2011) Vier neue Sesiiden und eine unbestimmte Homogyna-Art aus dem südlichen Afrika (Lepidoptera, Sesiidae: Osminiini, Sesiini). Nachrichten des Entomologischen Vereins Apollo, NF 31 (4), 211-218. Gaede, M. (1929) 22. Familie: Aegeriidae (Sesiidae). In: Seitz, A. (Ed.), Die Großschmetterlinge der Erde, Bd. 14. Die afrikanischen Spinner und Schwärmer. Alfred Kernen Verlag, Stuttgart, pp. 515-538, pl. 77.

Gray, J. E. (1868 [in lit. „27.6.1867’]). Notes on the Specimens of Calyptraeidae in Mr. Cuming's Collection. The Proceedings of the Zoological Society of London, 48, 726-748.

Häuser, C.L., Bartsch, D., Holstein, J. \& Steiner, A. (2003) The Lepidoptera type material of G.A.W. Herrich-Schäffer in the Staatliches Museum für Naturkunde, Stuttgart. Stuttgarter Beiträge zur Naturkunde, Serie A (Biologie), 657, 1-78.

Hampson, G.F. (1910) Descriptions of new African Moths. The Annals and Magazine of Natural History (Eighth Series), 5/6, 430-496, 116-141, 145-160. [Sesiidae 149-156] http://dx.doi.org/10.1080/00222931008692834

Hampson, G.F. (1919) A classification of the Aegeriadae of the Oriental and Ethiopian Regions. Novitates Zoologicae, 26 (1), 46-119.

Harvey, W.H. \& Sander, O.W. (1894) Flora Capensis, 2, Leguminosae to Loranthaceae. The Oast Hause Book, Kent, 622 pp.

Hatting, J.L., Brand, J. \& Damavandian, M.R. (2011) Phenology and behaviour of the clearwing moth, Monopetalotaxis candescens (Lepidoptera: Sesiidae), associated with cultivated rooibos, Aspalathus linearis (Fabaceae), in South Africa. African Entomology, 19 (1), 1-10. http://dx.doi.org/10.4001/003.019.0106

Heppner, J.B. (2010) Notes on Vietnam Moths, 14. Vespisesia a new clearwing moth genus and species from Vietnam (Lepidoptera: Sesiidae: Sesiinae). Lepidoptera Novae, 3 (3), 179-181.

Heppner, J.B. \& Duckworth, W.D. (1981) Classification of the Superfamily Sesioidea (Lepidoptera, Ditrysia). Smithsonian Contributions to Zoology, 314, 1-144. http://dx.doi.org/10.5479/si.00810282.314

Holland, W.J. (1893) Four new genera and species of West African Sesiidae. Journal of the New York Entomological Society, 1, $181-184$.

http://dx.doi.org/10.4039/ent251-1

Hübner, J. (1816-[1826]) Verzeichniß bekannter Schmettlinge [sic]. Augsburg, 432 pp. [Sesien, 127-130, (1819)]

Kallies, A. (2011) New species and taxonomic changes in Sesiini from Asia and Europe (Sesiidae). Nota lepidopterologica, 34 (2), 151-161 
Kallies, A. \& Arita, Y. (2004) A survey of the clearwing moths of the tribe Sesiini (Lepidoptera, Sesiidae) from Vietnam and adjacent countries with a synopsis of the Oriental Sesiini fauna. Tinea, 18 (1), 65-95.

Laštůvka, Z. \& Laštůvka, A. (2001) The Sesiidae of Europe. Apollo Books, Stenstrup, 245 pp.

Le Cerf, F. (1911) Description d'Aegeriidae nouvelles. Bulletin du Museum National d'Histoire Naturelle, 17 (5), $297-306$.

Le Cerf, F. (1916) Explication des planches. In: Oberthür, C. (Ed.), Études de Lépidoptérologie Comparée, 12 (1), 7-14, pls. 373-381.

Le Cerf, F. (1917) Contributions à l'étude des Aegeriidae. Description et Iconographie d'Espèces et de Formes nouvelles ou peu connues. In: Oberthür, C. (Ed.), Études de Lépidoptérologie Comparée, 14, 137-388, pls. 475-481.

Le Cerf, F. (1957) Nouveaux genres et espèces d'Aegeriidae de Madagascar [Lep.]. Bulletin de la Société entomologique de France, 62 (3/4), 97-100.

Meyrick, E. (1933) Aegeriadae. Exotic Microlepidoptera, 4, 415-417.

Nässig, W.A. \& Speidel, W. (2007) On the authorships of the Lepidoptera Atlas of the "Reise der Novara", with a list of the taxa of Bombycoidea [s.1.] therein described (Insecta, Lepidoptera, Bombycoidea). Senckenbergiana biologica, 87, 63-74.

Naumann, C.M. (1971) Untersuchungen zur Systematik und Phylogenese der holarktischen Sesiiden (Insecta, Lepidoptera). Bonner Zoologische Monographien, 1, 190 pp.

Palgrave, K.C. (1977) Trees of Southern Africa. C. Struik Publishers, Cape Town, South Africa, 959 pp.

Pretorius, G. (2008) Biodiversity Best Practice Guidelines for the Sustainable Production of Rooibos. Rooibos Biodiversity Initiative (RBI), Malmesbury, South Africa, $71 \mathrm{pp}$.

Pühringer, F. \& Sáfián, S. (2011) Two new species of Sesiini from Ghana, with description of a new genus (Lepidoptera, Sesiidae, Sesiinae, Sesiini). Nachrichten des Entomologischen Vereins Apollo, NF 31 (4), 231-235.

Pühringer, F. \& Kallies, A. (2004) Provisional checklist of the Sesiidae of the world (Lepidoptera: Ditrysia). Mitteilungen der Entomologischen Arbeitsgemeinschaft Salzkammergut, 4, 185. Available from: http://www.sesiidae.net/Checklst.htm (accessed 30 October 2013)

Špatenka, K., Gorbunov, O., Laštůvka, Z., Toševski, I. \& Arita, Y. (1999) Sesiidae, Clearwing Moths. In: Naumann, C.M. (Ed.), Handbook of Palaearctic Macrolepidoptera, 1. Gem Publishing Company, Wallingford, England, pp. 569.

Stephens, J.F. (1828) Family III. Sesiidae. Family IV. Aegeriidae. Haustellata. Illustrations of British Entomology; or, A Synopsis of Indigenous Insects: containing their generic and specific distinctions; with an account of their metamorphoses, times of appearancel, localities, food, and economy, as far as practicable, 1, 132-145, pls. 10-11.

Vári, L., Kroon, D.M. \& Krüger, M. (2002) Classification and Checklist of the species of Lepidoptera recorded in Southern Afrika. Simple Solutions, Chatswood, Australia, $384 \mathrm{pp}$.

Viette, P. (1957) Deux nouvelles Sesies de Madagascar (Lep. Aegeriidae). Le Naturaliste Malgache, 9 (1), 91-94.

Viette, P. (1982) Insectes Lépidoptères Sesiidae. Faune de Madagascar, 61, 64 pp.

Walker, F. (1856) Sphingidae. List of the Specimens of Lepidopterous Insects in the Collection of the British Museum, 8, 1-271. [8-72, 83-84, 260, 270 (index)]

Wallengren, H.D.J. (1859) Nya fjäril-slägten. Öfversigt af Kongliga Vetenskaps-Akademiens Förhandlingar, 15 (1858), 75-84, 135-142, 209-215.

Wallengren, H.D.J. (1863) Lepidopterologische Mittheilungen. III. Wiener entomologische Monatsschrift, 7 (5), $137-151$.

Wallengren, H.D.J. (1865) Heterocer-Fjärilar, samlade i Kafferlandet af J.A. Wahlberg. Kongliga Svenska VetenskapsAkademiens Handlingar, N.F. 5 (4) (1864), 1-83. 